\title{
Sentinel Lymph Node Mapping in Colon Cancer Patients: Does Make A Sense?
}

\section{Kolon Kanseri hastalarında Sentinel lenf nodu haritalandırması: Bir anlamı var mı?}

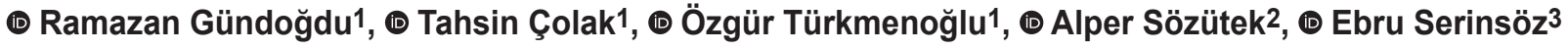 \\ ${ }^{1}$ Mersin University Faculty of Medicine, Department of General Surgery, Mersin, Turkey \\ 2Adana Numune Training and Research Hospital, Clinic of Division of Gastroenterological Surgery, Adana, Turkey \\ ${ }^{3}$ Mersin University Faculty of Medicine, Department of Pathology, Mersin, Turkey
}

\section{HIIIIIII ABSTRACT}

Aim: Lymph node status in colon cancer (CC) is a major prognostic factor that determines the disease recurrence, survival, and the adjuvant treatment. Although sentinel lymph node (SLN) is an effective technique that improves pathologic assessment in breast cancer and melanoma, the feasibility and outcomes of SLN in CC is still controversial. Hence, we aimed to evaluate the sensitivity, specificity, and accuracy of SLN for determining lymph node status in CC.

Method: A total of 84 consecutive patients undergoing urgent or elective colectomy for colon cancer were enrolled in this prospective randomized study. In vivo SLN mapping with blue dye was used to evaluate the lymph node status. The sensitivity of the method was evaluated by comparing the pathologic condition of 3-4 blue dyed lymph nodes with final conventional pathologic assessment.

Results: The sensitivity of identification for SLN was low (61.54\%) for predicting lymph node metastasis, false-negative rates were high (38.5\%), specificity was $100 \%$, the detection rate was $88.1 \%$, the overall accuracy rate was $81.08 \%$, negative predictive value $82.76 \%$, and positive predictive value was $100 \%$. No upstaging was determined in our study.

Conclusion: Considering our results, SLN mapping could not predict the nodal status with clinically acceptable accuracy despite a high detection rate. We emphasize that en bloc tumor resection with regional lymph node dissection is still the standard treatment for CC. SLN mapping should not alter the extent of the operation due to its low predictive value.

Keywords: Sentinel lymph node, colorectal cancer, staging, lymph node metastasis

\section{|IIIIIIII|| ÖZ}

Amaç: Kolorektal kanserlerde (CC) lenf nodu tutulumu, hastalığın nüksü, sağkalım ve adjuvan tedaviye karar vermede majör prognostik faktör olarak değerlendirilir. Sentinel lenf nodu (SLN) meme ve melonomada patolojik değerlendirmeyi güçlendiren etkili bir teknik olsa da CC'de halen tartışmalıdır. Bu nedenle, bu çalışmada SLN'nin CC'de lenf nodu durumunu değerlendirmesindeki duyarlılığı, özgüllüğü ve doğruluğunu değerlendirmeyi amaçladık.

Yöntem: Bu prospektif randomize çalışmaya, kolorektal kanser nedeniyle acil veya elektif ameliyata alınacak olan ardışık 84 hasta dahil edildi. Lenf nodu durumunu değerlendirmek için "in vivo" mavi boya ile haritalama yöntemi kullanıldı. Yöntemin duyarlılığı mavi boya ile ilk boyanan 3-4 lenf nodunun nihai patoloji raporuyla karşılaştırılarak değerlendirildi.

Bulgular: SLN'nin metastatik lenf nodunu tahmin $(\% 61,54)$ etmedeki belirleyiciliği az, yalancı-negatiflik oranı yüksek (\%38,5), özgüllügü \%100, tahmin oranı \%88,1 idi. Genel doğruluğu \%81,08, negatifi tahmin değeri \%82,76, pozitifi tahmin değeri ise \%100 idi. Bizim çalışmamızda olduğundan daha ileri (upstaging) bir evreleme yapılmadı.

Sonuç: Bu sonuçlar göz önünde bulundurulduğunda, SLN haritalaması, yüksek tespit oranına rağmen hastanın lenf nodu durumunu klinik olarak kabul edilebilir doğrulukla tahmin edemedi. Çalışmada bölgesel lenf nodu disseksiyonuyla birlikte yapılan "en bloc" tümör rezeksiyonunun CC'lerde halen standart tedavi yöntemi olduğunu vurgulamaktayız. SLN haritalaması düşük prediktif değerinden dolayı, operasyonun niteliğini değiștirmemelidir.

Anahtar Kelimeler: Sentinel lenf nodu, kolorektal kanser, evreleme, lenf nodu metastazı

Address for Correspondence/Yazışma Adresi:Tahsin Çolak,

Mersin University Faculty of Medicine, Department of General Surgery, Mersin, Turkey

Phone: +90 5357730229 E-mail: colaktahsin@yahoo.com ORCID ID: orcid.org/0000-0002-7253-5608

Received/Geliş Tarihi: 02.08.2019 Accepted/Kabul Tarihi: 24.08.2019

${ }^{\circ}$ Copyright 2020 by Turkish Society of Colon and Rectal Surgery

Turkish Journal of Colorectal Disease published by Galenos Publishing House. 


\section{Introduction}

Colorectal cancer is the most encountered malignancy in the gastrointestinal tract and second leading cause of death among all cancers. Survival after radical surgery is strongly associated with the stage of the disease including lymph node status. The existence of metastasis in the lymph nodes (LN) decreases 5-year survival at a rate of 20-30\%.,

In fact, extended dissection and careful examination of LN increase the possibility of detecting the nodal metastasis. ${ }^{3}$ As Goldstein et al. ${ }^{4}$ have stated there is a strong correlation between the number of dissected LN in the specimen and the rate of lymph node metastasis. HE- stained section and paraffin-embedded block is still the most performed method by pathologists to evaluate the LN of the specimen. However, this conventional histopathologic examination may sometimes underestimate the true incidence of lymph node involvement due to the failure of detecting occult nodal micrometastasis. Unfortunately, this lack of the examination may cause recurrence in approximately 20$30 \%$ of the patients with node-negative early stage disease. ${ }^{5,6}$ Recurrence is related to several factors including inadequate lymph node resection at the time of surgery, inadequate sampling of the involved LN within the resected specimen, and failure to identify small-volume occult metastasis on pathologic assessment (micrometastasis). ${ }^{7}$

The concept of lymphatic mapping is based on the principle that each anatomic site has specific lymphatic drainage to a designated lymph node. A cancer that has spread beyond the primary tumor site will drain through the regional lymphatic into this first lymph node or chain of lymph nodes, termed the sentinel lymph node (SLN). ${ }^{8}$ Detailed examination of every lymph node removed in a standard colon resection is generally labor-intensive and costly. However, SLN has a potential to obviate this obstacle by limiting the number of LN to be evaluated. Hence, this may allow the pathologist to perform a more detailed analysis on specific LN by serial sectioning, also immunohistochemical (IHC) staining to identify micrometastasis, as well. During the last two decades, lymphatic mapping and sentinel lymph node biopsy (SLNB) have gained popularity due to accurate staging of solid neoplasms especially in breast cancer and melanoma. ${ }^{9,10}$ Thus, this condition encourages the surgeons to improve the staging of gastrointestinal cancers and decision of adjuvant treatment. However, considering the results of several studies about SLNB, it is obvious that the debate about the feasibility and outcomes of the technique in colon cancer (CC) still continues. Hence, we conducted this study to evaluate the sensitivity, specificity, and accuracy of SLNB for determining lymph node status in patients undergoing surgery for colon cancer.

\section{Patients and Methods}

After obtaining our institution's ethics committee approval, the study was conducted in Mersin University Medical Faculty Training and Research Hospital, Department of General Surgery in a period between October 2010 and October 2011. A total of consecutive 100 patients undergoing urgent or elective colectomy for CC were enrolled in this study. Patients were excluded in cases of aged less than 18 years, American Society of Anesthesiologists (ASA) scores V, food allergy, receiving radiotherapy, previous colon resection for benign or malign disease, recurrence and distant metastasis. Hence, one patient with food allergy, 2 patients with previous colon resection, 3 patients with recurrence, 6 patients with distant metastasis, and 4 patients who rejected the study were excluded. Finally, the study included 84 patients. A written informed consent concerning the surgical risks was obtained from all patients.

\section{Surgical Technique}

All patients were prepared to surgery routinely. No bowel preparation was performed. A single dose of $1 \mathrm{~g}$ cefazolin sodium and metronidazole $0.5 \% 100 \mathrm{~mL}$ was applied for prophylaxis. All patients underwent radical open surgery according to the localization of the tumor (right/left hemicolectomy, anterior resection, subtotal colectomy) under general anesthesia. Patent blue was applied into the subserosal layer of the colon around the tumors for SLN mapping. Before resection, 2-4 $\mathrm{mL}$ of patent blue was injected with a distance of $1 \mathrm{~cm}$ to four quadrants of the tumor and waited for 10 minutes. The first stained three or four LN were accepted as SLN and marked with $2 / 0$ silk suture. Subsequently, radical surgery was accomplished in accordance with oncological principles. The histopathological examination of the specimen was done after marking. Dyed LN were first evaluated with hematoxylin-eosin and if metastasis was not detected, IHC pancytokeratin was applied. Histopathological examination of the first dyed three or four LN was compared to the final pathologic examination of the specimen. Patients were evaluated with regard to their demographic characteristics and tumor localization. The specimen was evaluated with regard to the number of stained, metastatic, total resected LN and the compatibility with the final pathologic stage of the tumor.

\section{Statistical Analysis}

Statistical MedCalc 9.3.9.0 software was used for statistical analysis. In this study, we assumed at least one SLN to be dyed with the standard deviation of two, and a sample size was calculated so that at least 78 patients were needed to provide $0.05 \alpha$ and $0.01 \beta$ error. Hence, considering the patients would be excluded during the study, the sample 
size was accepted as 100 patients. The data obtained were summarized in a computerized spreadsheet and statistical analyses were performed by using SPSS 11.5 for Windows. Numerical data were presented as mean \pm standart deviation and categorical data were expressed as number and percent (\%). Sensitivity, specificity, detection rate, accuracy rate, false-negative rate, and positive-negative predictive value of the method were analyzed to evaluate the applicability of the procedure.

\section{Results}

A total of 84 patients including 40 (47.6\%) male and 44 (52.4\%) female with a median age of 64.5 (41-87) years were enrolled in the study. Fifty-four patients (64.3\%) were ASA II, 28 (33.3\%) were ASA III, and 2 (2.4\%) were ASA IV. Twenty-two (26.2\%) of the operations were urgent while 62 (73.8\%) were elective. In our study, 44 (52.4\%) patients underwent right or extended right hemicolectomy, $10(11.9 \%)$ patients underwent left or extended left hemicolectomy, 28 (33.3\%) patients underwent anterior resection, and 2 (2.4\%) patients underwent subtotal colectomy. The histopathological examination of the specimen revealed adenocarcinoma (83.3\%), mucinous carcinoma (14.3\%), and neuroendocrine carcinoma (2.4\%). The tumor localization was ceacum in 22 (26.2\%), right colon in $16(19 \%)$, transverse colon in 8 (9.5\%), left colon in 8 (9.5\%), and sigmoid colon in 30 (35.7\%) patients.

In this study, no staining was observed in 10 (11.9\%) patients. However, one area in $2(2.4 \%)$ patients, two areas in $2(2.4 \%)$ patients, three areas in $58(69 \%)$ patients and four areas in 12 (14.3\%) patients were stained and marked. The presence of lymph node in all four of the marked areas was detected for 6 patients (7.1\%), three marked areas with lymph node in 36 patients (42.9\%), two marked areas with lymph node in 22 patients $(26.2 \%)$, and one marked area with lymph node in 10 (11.9\%) patients. The T staging of the tumor was pT2 in 10 (11.9\%), pT3 in $56(66.7 \%)$, and pT4 in $18(21.4 \%)$ patients. The pathologic staging of resected LN was as follows: N0 in 54 (64.3\%), N1 in 14 (16.7\%), and $\mathrm{N} 2$ in 16 (19.0\%) patients. An average of 24 (5-48) LN were removed in final pathology. There was no staining in 10 of 84 patients; however, at least one lymph node was stained in the rest of the patients. The distribution of the patients according to the stage of the tumor, number of dyed areas, lymph node status of the dyed area, number of dyed LN and metastasis in LN was summarized in Figure 1.

Finally, there was no metastasis in $58(69 \%)$ patients with stained lymph nodes. Macrometastasis was detected in $26(31 \%)$ patients. There were macrometastasis in stained lymph nodes (SLN) in 16 of these patients, and 10 (12\%)
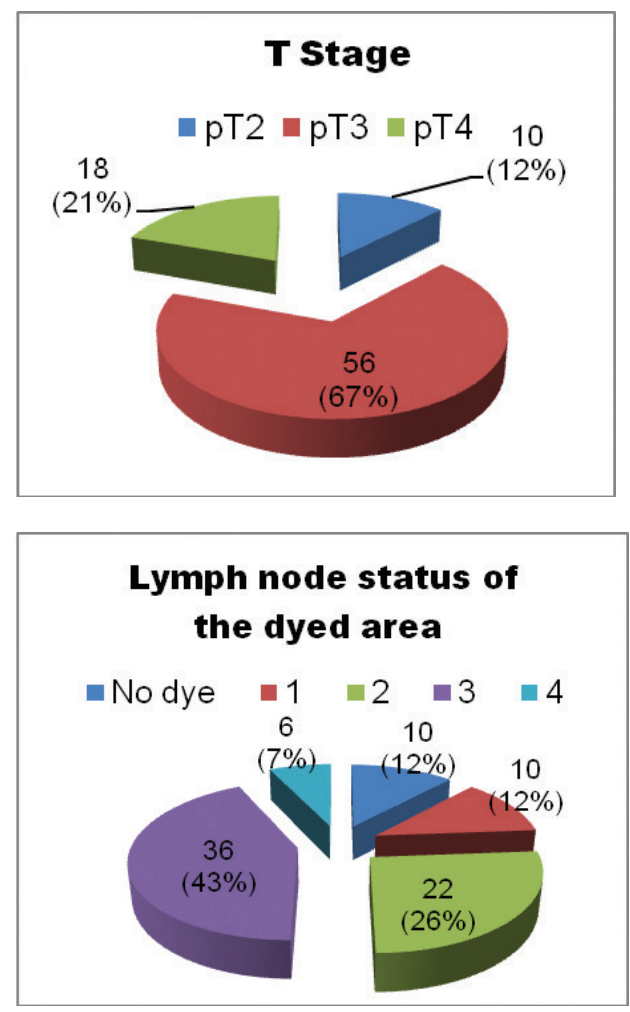
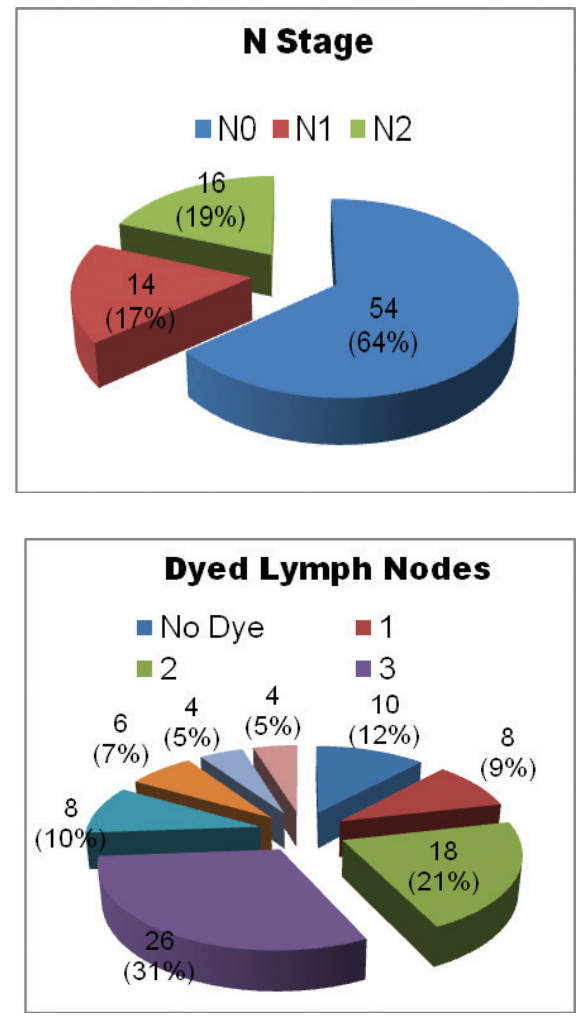
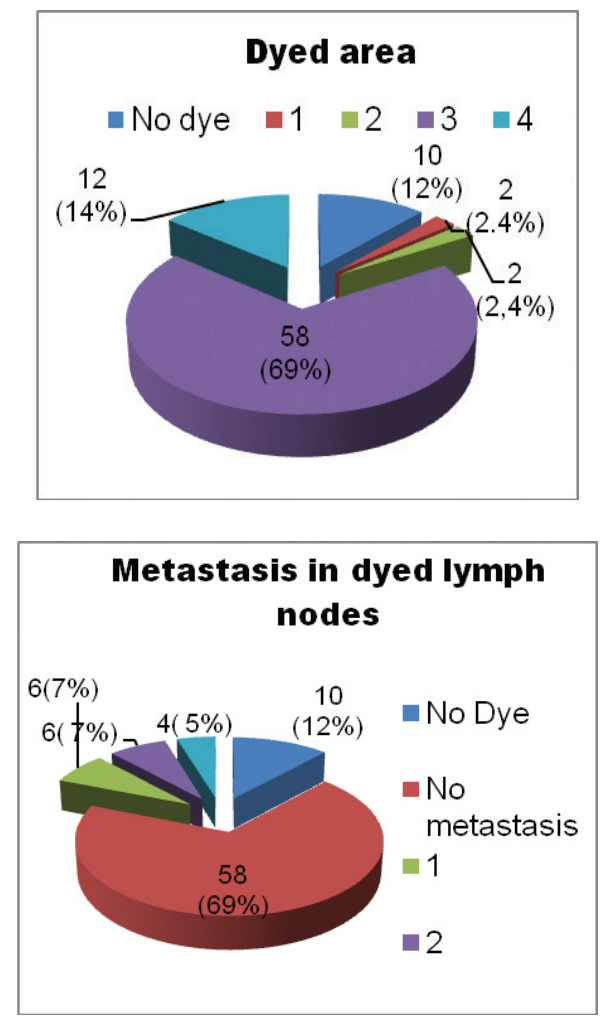

Figure 1. The distribution of the patients according to the stage of the tumor and pathologic assessment of the dyed lymph nodes 
patients had macrometastases in undyed lymph nodes (nonSLN) (Figure 2).

The sensitivity of identification for SLN was low (61.54\%) for predicting lymph node metastasis, false-negative rates were high (38.5\%), specificity was $100 \%$, the detection rate was $88.1 \%$, the overall accuracy rate was $81.08 \%$, negative predictive value was $82.76 \%$, and positive predictive value was $100 \%$ (Table 1). Aberrant lymphatic drainage was not detected.

\section{Discussion}

Lymph node status in CC is a major prognostic factor that determines the disease recurrence, survival, and the adjuvant treatment. ${ }^{8,11,12,13,14}$ Disease recurrence still remains the most important problem after radical surgery likely due to inadequate lymph node dissection. The optimal number of LN required to accurately predicting lymph node negativity has been a point of debate. The view of identifying at least $12 \mathrm{LN}$ in the specimen is considered proper for staging of CC by many clinicians. In contrast to

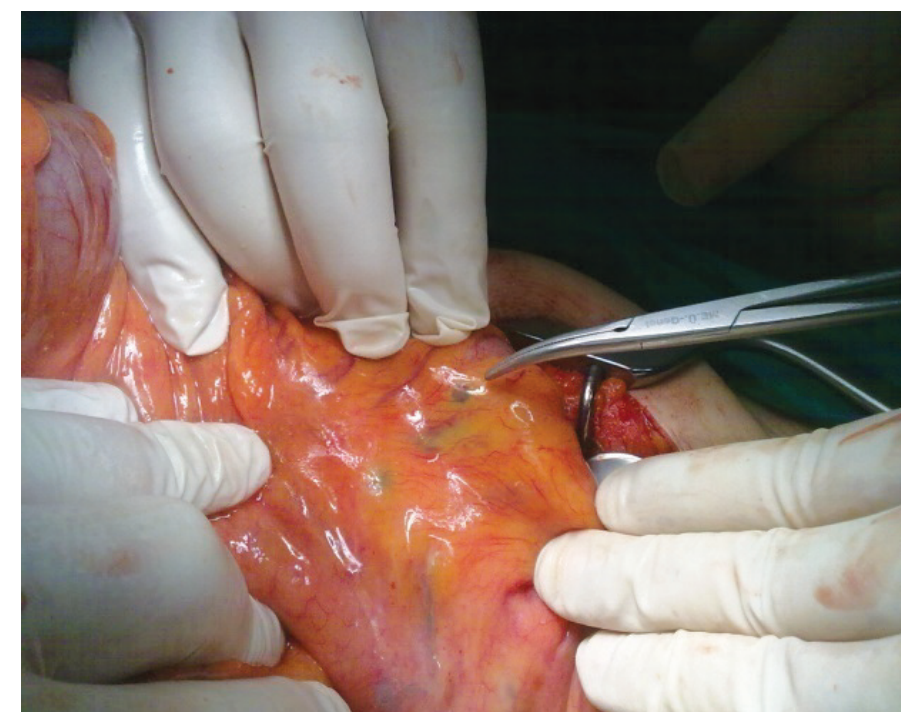

Figure 2. In vivo SLN mapping in CC (The tip of clamp reveals a blue dyed metastatic lymph node)

SLN: Sentinel lymph node, CC: Colon cancer

Table 1. The evaluation of SLN mapping in CC patients

$\begin{array}{ll}\text { Sensitivity } & 61.54 \%(40.57 \%-79.77 \%) \\ \text { Specificity } & 100 \%(92.60 \%-100 \%) \\ \text { Detection rate } & 88.1 \% \\ \text { Overall accuracy rate } & 81.08 \% \\ \text { False negative rate } & 38.5 \% \\ \text { Positive predictive value } & 100 \% \\ \text { Negative predictive value } & 82.76 \%\end{array}$

this view, survival is found to be strongly associated with the number of studied LN in recent studies. ${ }^{4,15}$ Hence, extended lymph node dissection (total mesocolic excision) (ELND) has been raised and better results have been obtained. ${ }^{15,16}$ Recently, SLN mapping has been tried to facilitate ELND and to improve stating accuracy in CC. . $^{12,13,14,17}$ However, notwithstanding our results, the feasibility of SLN in CC seems to be controversial and still remains to be defined. Hence, this study was planned.

The standard approach for lymph node evaluation in the specimen is based on manual dissection and histological evaluation of HE stained slides. ${ }^{18}$ Unfortunately, this conventional approach, especially by single section, allows analyzing only $1 \%$ of LN tissue and usually fails to identify micrometastasis. This leads to $70 \%$ of infiltrated LN that are smaller than $5 \mathrm{~mm}$ and with subcapsular location remain undetected. Unfortunately, this lack of the examination may cause recurrence in approximately $20-30 \%$ of the patients with node-negative early stage disease. ${ }^{7}$ Therefore, efforts have been made to improve pathologic stating of CC by identifying micrometastasis which is not detectable by conventional histopathologic techniques. Recently, SLN mapping in CC has been applied to enhance pathologic assessment.

SLN biopsy has been proposed as a simple, inexpensive and feasible method that allows accurate stating of CC in many studies with an advantage of short learning curve. ${ }^{12}$ However, it is noteworthy that high variable rates of accuracy and sensitivity have been reported in the literature. Considering the results of SLN in CC, the detection rate and the false negative rate range from $59 \%$ to $99 \%$ and from $7,5 \%$ to $60 \%$, respectively. ${ }^{5,8,12,13,14,17,18,19,20}$ Among these studies, our results were consistent with the results of a multicenter study sponsored by "Cancer and Leukemia Group-B (CALGB)"20 and S.J. Lim et al. ${ }^{8}$ demonstrated a sensitivity of $46 \%-41 \%$, a false-negative rate of $54 \%-41 \%$, and the overall accuracy rate of $80 \%-83 \%$, respectively. According to our results, we emphasize that SLN mapping in CC could not predict node positivity due to its low sensitivity and high false negativity despite a high detection rate. However, our high false negative rate may be related to our high proportion of T3/T4 patients. In our opinion, the significant differences between these reports including our study are more likely due to inclusion criteria or skip metastasis. Furthermore, these results mainly depend on the experience of the team performing the procedure and the amount of infiltrated dye. It is notable that SLN mapping in CC surgery has to be assessed different from mapping in melanoma or breast cancer. Although the first dyed node has a prognostic importance in melanoma or breast cancer, in CC, the number of dyed LN retrieved from the specimen appears to 
be important for targeted nodal assessment due to the watershed distribution of the colon's lymphatic basin. ${ }^{18}$ In other words, expectation from SLN mapping in CC is to help more accurate stating of stage II patients who have undetectable micrometastasis by conventional histopathologic techniques. At the beginning of our study, we expect to receive the same results from SLN mapping in CC, so that we enhance pathologic assessment of LN by HE and cytokeratin IHC stained step sections. However, our results did not support our hypothesis. Although Bembenek et al. ${ }^{21}$ detected micrometastasis or isolated tumor cells by examination of SLNB with IHC staining in $21 \%$ of node-negative patients and Sardón Ramos et al. ${ }^{13}$ received upstaging at a rate of $14 \%$ of the patients, no upstaging was determined in our study. Our results with IHC staining were compatible with the results of conventional examination. In our opinion, this finding is not associated with our technical error; it is more likely due to the majority of our patients with T3/T4 tumor. Because we believe that bulky tumor or invasion leads to obstruct the lymphatic channels, hence this disrupts proper dye spread via the lymphatic circulation.

Lymphatic drainage that extends beyond the planned resection margins may lead to skip metastasis so should be considered in disease recurrence. It is reported that skip metastasis is usually related to anatomic variations of lymphatic drainage pathways. ${ }^{13,18}$ Detecting this aberrant nodal dissemination beyond the limits of surgery has been advocated as another principal advantage of SLN mapping in CC, thus loco-regional recurrence may be prevented. Bilchik et al. ${ }^{22}$ have detected aberrant lymphatic pathways by SLN mapping in a majority of his patients. In another study, Coccetta et al..$^{23}$ detected the rate of skip metastasis as $20 \%$ by SLN with IHC methods. However, no aberrant lymphatic pathways were detected in this study.

\section{Conclusion}

Although SLN mapping in CC surgery has been offered as a feasible method that allows accurate stating of CC, its clinical value should still be tested by large prospective studies. Considering our results, we suggested that SLN mapping could not predict the nodal status with clinically acceptable accuracy despite a high detection rate. Furthermore, we emphasize that en bloc tumor resection with regional lymph node dissection is still the standard treatment for CC. SLN mapping should not alter the extent of the operation due to its low predictive value. Surgeons should avoid conservative resection by relying on SLN results in CC surgery, which may lead to result under-treatment.

\section{Ethics}

Ethics Committee Approval: After obtaining our institution's ethics committee approval, the study was conducted in Mersin University Medical Faculty Training and Research Hospital, Department of General Surgery in a period between October 2010 and October 2011.

Informed Consent: A written informed consent concerning the surgical risks was obtained from all patients.

Peer-review: Internally and externally peer reviewed.

\section{Authorship Contributions}

Surgical and Medical Practices: R.G., T.Ç., Ö.T., A.S., E.S., Concept: T.Ç., Design: Ö.T., Data Collection or Processing: R.G., Analysis or Interpretation: R.G., T.C.., A.S., E.S., Literature Search: R.G., Ö.T., A.S., E.S., Writing: R.G., A.S.

Conflict of Interest: No conflict of interest was declared by the authors.

Financial Disclosure: This prospective research was conducted in Mersin University Medical Faculty.

\section{References}

1. Herrera-Ornelas L, Justiniano J, Castillo N, Petrelli NJ, Stulc JP, Mittelman A. Metastases in small lymph nodes from colon cancer. Arch Surg $1987 ; 122: 1253-1256$

2. Joosten JJ, Strobbe LJ, Wauters CA, Pruszczynski M, Wobbes T, Ruers TJ. Intraoperative lymphatic mapping and the sentinel node concept in colorectal carcinoma. Br J Surg 1999;86:482-486.

3. Hida JI, Yasutomi M, Maruyama T, Fujimoto K, Uchida T, Okuno K. The extent of lymph node dissection for colon carcinoma. The potential impact on laparoscopic surgery. Cancer 1997;80:188-192.

4. Goldstein NS, Sanford W, Coffey M, Layfield LJ. Lymph node recovery from colorectal specimens removed for adenocarcinoma. Trend over time and recommendation for a minimum number of lymph nodes to be recovered. Am J Clin Pathol 1996;106:209-216.

5. Saha S, Wiese D, Badin J, Beutler T, Nora D, Ganatra BK, Desai D, Kaushal S, Nagaraju M, Arora M, Singh T. Technical details of sentinel lymph node mapping in colorectal cancer and its impact on staging. Ann Surg Oncol 2000;7:120-124.

6. Bertoglio S, Percivale P, Gambini C, Dicasa D, Meszaros P, Sciallero S, Bruzzi P, Badellino F. Cytokeratin immunostaining reveals micrometastasis in negative hematoxylin-eosin lymph nodes of resected stage I-II (pT2pT3) colorectal cancer. J Chemother 1997;9:119-120.

7. Sargent DJ, Wieand HS, Haller DG, Gray R, Benedetti JK, Buyse M, Labianca R, Seitz JF, O'Callaghan CJ, Francini G, Grothey A, O'Connell M, Catalano PJ, Blanke CD, Kerr D, Green E, Wolmark N, Andre T, Goldberg RM, De Gramont A. Disease-free survival versus overall survival as a primary end point for adjuvant colon cancer studies: individual patient data from 20, 898 patients on 18 randomized trials. J Clin Oncol 2005;23:8664-8670.

8. Lim SJ, Feig BW, Wang H, Hunt KK, Rodriguez-Bigas MA, Skibber JM, Ellis V, Cleary K, Chang GJ. Sentinel lymph node evaluation does not improve staging accuracy in colon cancer. Ann Surg Oncol 2008;15:46-51.

9. Veronesi U, Paganelli G, Viale G, Luini A, Zurrida S, Galimberti V, Intra M, Veronesi P, Robertson C, Maisonneuve P, Renne G, De Cicco C, De Lucia F, Gennari R. A randomized comparison of sentinel-node biopsy with routine axillary dissection in breast cancer. N Engl J Med 2003;349:546-553.

10. Morton DL, Thompson JF, Cochran AJ, Mozzillo N, Nieweg OE, Roses DF, Hoekstra HJ, Karakousis CP, Puleo CA, Coventry BJ, Kashani-Sabet M, Smithers BM, Paul E, Kraybill WG, McKinnon JG, Wang HJ, Elashoff R, Faries MB; MSLT Group. Final trial report of sentinel-node biopsy versus nodal observation in melanoma. N Engl J Med 2014;370:599-609. 
11. Chang GJ, Rodriguez-Bigas MA, Skibber JM, Moyer VA. Lymph node evaluation and survival after curative resection of colon cancer: systematic review. J Natl Cancer Inst 2007;99:433- 441.

12. Bertoglio S, Sandrucci S, Percivale P, Goss M, Gipponi M, Moresco L, Mussa B, Mussa A. Prognostic value of sentinel lymph node biopsy in the pathologic staging of colorectal cancer patients. J Surg Oncol 2004;85:166170.

13. Sardón Ramos JD, Errasti Alustiza J, Campo Cimarras E, Cermeño Toral B, Romeo Ramírez JA, Sáenz de Ugarte Sobrón J, Atares Pueyo B, Moreno Nieto V, Cuadra Cestafe M, Miranda Serrano E. Sentinel lymph node biopsy technique in colon cancer. Experience in 125 cases. Cir Esp 2013;91:366371.

14. Oh SY, Kim do Y, Kim YB, Suh KW. Clinical application of sentinel lymph node mapping in colon cancer: in vivo vs. ex vivo techniques. Ann Surg Treat Res 2014:87:118-122.

15. Hida J, Okuno K, Yasutomi M, Yoshifuji T, Uchida T, Tokoro T, Shiozaki H. Optimal ligation level of the primary feeding artery and bowel resection margin in colon cancer surgery: the influence of the site of the primary feeding artery. Dis Colon Rectum 2005;48:2232-2237.

16. Hohenberger W, Weber K, Matzel K, Papadopoulos T, Merkel S. Standardized surgery for colonic cancer: complete mesocolic excision and central ligation-technical notes and outcome. Colorectal Dis 2009;11:354-364.

17. Lim SJ, Feig BW, Wang H, Hunt KK, Rodriguez-Bigas MA, Skibber JM, Ellis V, Cleary K, Chang GJ. Sentinel lymph node evaluation does not improve staging accuracy in colon cancer. Ann Surg Oncol 2008;15:46-51.

18. Stojadinovic A, Nissan A, Protic M, Adair CF, Prus D, Usaj S, Howard RS, Radovanovic D, Breberina M, Shriver CD, Grinbaum R, Nelson JM, Brown
TA, Freund HR, Potter JF, Peretz T, Peoples GE. Prospective randomized study comparing sentinel lymph node evaluation with standard pathologic evaluation for the staging of colon carcinoma: results from the United States Military Cancer Institute Clinical Trials Group Study GI-01. Ann Surg 2007;245:846-857.

19. Saha S, Sehgal R, Patel M, Doan K, Dan A, Bilchik A, Beutler T, Wiese D, Bassily N, Yee C. A multicenter trial of sentinel lymph node mapping in colorectal cancer: prognostic implications for nodal staging and recurrence. Am J Surg 2006;191:305-310.

20. Bertagnolli M, Miedema B, Redston M, Dowell J, Niedzwiecki D, Fleshman J, Bem J, Mayer R, Zinner M, Compton C. Sentinel node staging of resectable colon cancer: results of a multicenter study. Ann Surg 2004;240:624-628; discussion 628-630.

21. Bembenek AE, Rosenberg R, Wagler E, Gretschel S, Sendler A, Siewert JR, Nährig J, Witzigmann H, Hauss J, Knorr C, Dimmler A, Gröne J, Buhr HJ, Haier J, Herbst H, Tepel J, Siphos B, Kleespies A, Koenigsrainer A, Stoecklein NH, Horstmann O, Grützmann R, Imdahl A, Svoboda D, Wittekind C, Schneider W, Wernecke KD, Schlag PM. Sentinel Lymph Node Biopsy in Colon Cancer A Prospective Multicenter Trial. Ann Surg 2007;245:858-863.

22. Bilchik AJ, Saha S, Tsioulias GJ, Wood TF, Morton DL. Aberrant drainage and missed micrometastases: the value of lymphatic mapping and focused analysis of sentinel lymph nodes in gastrointestinal neoplasms. Ann Surg Oncol 2001;8:82-85.

23. Coccetta M, Covarelli P, Cirocchi R, Boselli C, Santoro A, Cacurri A, Grassi V, Barillaro I, Koltraka B, Spizzirri A, Pressi E, Trastulli S, Gullà N, Noya G, Sciannameo F. The sentinel lymph node mapping in colon cancer. G Chir 2010;31:556-559 